\title{
THE ARCHIGINNASIO, THE SEAT OF THE UNIVERSITY OF BOLOGNA IN MODERN TIMES
}

The Alma Mater Studiorum of Bologna, believed to be the first university in the Western world, began its life towards the end of the $11^{\text {th }}$ century, when the masters of grammar, rhetoric and logic opened a school of juridical studies. Thereafter, teaching independent of the ecclesiastical schools became rooted in the city and the school became famous beyond its borders due to some of its most illustrious masters, such as the glossarist Irnerius and his disciples and followers (Bulgarus, Martinus Gosia, Jacobus and Hugo de Porta Ravennate). ${ }^{1}$ Originally, the free collectio of funds among the disciples guaranteed the teaching. However, there was no regular method of financing until the municipality of Bologna assumed responsibility for the costs and thereby stabilised the city's schools; Frederick Barbarossa also moved to protect the young institution with an Imperial Constitution (1158) that was supposed to safeguard the teaching from the intrusion of external authorities and scholares who were travelling for reasons of study. Moreover, the students themselves gained strength based on their origins: on the one hand, there was the Citramontani (from near the Alps on the Italian peninsula, but not the Bolognese, Lombards,

DOI: https://doi.org/10.12697/BJAH.2018.15.06

A special thanks to Ilaria Maggiulli and Ugo Dovere.

1 Cf. Enrico Spagnesi, Wernerius Bononiensis iudex. La figura storica d'Irnerio (Firenze: Olschki, 1970). 
Tuscans or Romans), and on the other, the Ultramontani (non-Italians living beyond the Alps, including the French, Spanish, Provencal, English, Picards, Burgundians, Normans, Catalans, Hungarians, Poles, Germans, etc.).

The concept and economic autonomy of the university made the student body grow - in the $14^{\text {th }}$ century, there were more than two thousand students. This also enriched the teaching because the jurists were flanked by artisti or scholars of medicine, philosophy, arithmetic, astronomy, logic, rhetoric and grammar, and, as of 1364, also theology. Over time, the teaching was updated and enriched, not only with Greek and Hebrew, but also new disciplines, such as 'natural magic' or experimental science, which was well represented by the philosopher Pietro Pomponazzi ${ }^{2}$, scientist Ulisse Aldrovandi ${ }^{3}$ and plastic surgeon Gaspare Tagliacozzi. ${ }^{4}$ The great European intellectuals - from Dante to Petrarch, Thomas Becket to Paracelsus, Ramon de Penyafort to Albrecht Dürer, Carlo Borromeo to Torquato Tasso - loved to visit the University of Bologna. Pico della Mirandola and Leon Battista Alberti studied canon law there, as did Nicolaus Copernicus who, at the same time, pursued his astronomical observations.

As the institution was becoming consolidated and its image was being disseminated abroad, the need grew for a building that could reflect the antiquity of the institution, and also make it possible to improve the university's potential in the new era envisioned in the $16^{\text {th }}$ century. Indeed, this was when people started talking about a single and prestigious seat for the Bolognese university, that would be - as Michel de Montaigne observed in 1580 - the most beautiful building dedicated to the teaching of the sciences. ${ }^{5}$

2 Cf. Francesco Fiorentino, Pietro Pomponazzi. Studi storici su la scuola bolognese e padovana del secolo XVI [1868] (Napoli: La scuola di Pitagora, 2008); Pietro Pomponazzi: tradizione e dissenso. Atti del Congresso internazionale di studi su Pietro Pomponazzi, Mantova 23-24 ottobre 2008, ed. by Marco Sgarbi (Firenze: Olschki, 2010).

3 Cf. Ulisse Aldrovandi: Natura picta, ed. by Alessandro Alessandrini, Alessandro Ceregato (Bologna: Editrice Compositori, 2007); Angela Fischel, Natur im Bild. Zeichnung und Naturerkenntnis bei Conrad Gessner und Ulisse Aldrovandi (Berlin: Gebr. Mann, 2009); Marinela Haxhiraj, Ulisse Aldrovandi. Il museografo (Bologna: Bononia University Press, 2016).

4 Cf. Martha Teach Gnudi, Jerome Pierce Webster, The Life and Times of Gaspare Tagliacozzi Surgeon on Bologna 1545-1599, with a Documented Study of the Scientific and Cultural Life of Bologna in the Sixteenth Century (Milano, New York: U. Hoepli, H. Reichner, 1950).

5 Cf. Michel de Montaigne, Journal du voyage de Michel de Montaigne en Italie, par la Suisse \& l'Allemagne en $1850 \& 1851$. Avec des notes par M. De Querlon, vol. 2 (Rome, Paris: Chez Le Jay, 1774), 36-37. 


\section{THE PALAZZO OF THE ARCHIGINNASIO}

When Montaigne looked with admiration at the 'palace of sciences' in the heart of Bologna, the building was not yet twenty years old. Commissioned by Cardinal Carlo Borromeo who, assisted by Pier Donato Cesi, acted as papal legate at the time, the beautiful complex of the Archiginnasio was designed by Antonio Morandi, engineer of the Fabbrica di San Petronio. ${ }^{6}$ Quickly completed by 1563, while a definitive form was being given to the centrally located Piazza Maggiore and the fascinating fountain of Neptune was being erected (1564), ${ }^{7}$ it housed all the university's departments, which had been scattered in the various locations until then. Until 1803, the palazzo of the Archiginnasio was the prestigious and functional seat of the University of Bologna. Later, the school would move to the Palazzo Poggi, while the central building of the Archiginnasio became the municipal library (1838).

At the dawn of the $18^{\text {th }}$ century, the Dominican Jean-Baptiste Labat, a disillusioned and worldly-wise observer, who was in Bologna for the general chapter of the order in 1706, explicitly understood the grandeur and the magnificence of the building. However, he observed with cautionary sarcasm the risk of damage that could be caused by the students, who had notoriously little respect for the places they frequented, and were accustomed to writing their names everywhere and scribbling the worst things. ${ }^{8}$ On the other hand, at the end of the century, Goethe, who was not fully involved, passed through Bologna in the autumn of 1786, and noticed the 'many nice things' collected in the palazzo degli Studi, but remarked on the excessive severity of the place, commenting that it was perhaps too austere to nurture studies by Germans who were used to a freer style of study. ${ }^{9}$

6 Cf. Gabriella Manzini, 'Antonio Morandi, il "Terribilia”, nell'architettura bolognese del '500', Il Carrobbio, 9 (1983), 243-255; Valeria Rubbi, 'Sull'architettura del Cinquecento: Antonio Morandi, detto il "Terribilia", L'architettura del Rinascimento a Bologna. Passione e filologia nello studio di Francesco Malaguzzi Valeri (Bologna: Editrice Compositori, 2010), 123-143.

7 On the urban policies of Pius IV cf. Richard J. Tuttle, Piazza Maggiore. Studi su Bologna nel Cinquecento (Venezia: Marsilio, 2001); Francesco Ceccarelli, 'Scholarum extraedificatio. La costruzione del palazzo dell'Archiginnasio e la piazza delle scuole di Bologna', L'università e la città. Il ruolo di Padova e degli altri atenei italiani nello sviluppo urbano. Atti del convegno di studi. Padova, 4-6 dicembre 2003, ed. by Giuliana Mazzi (Bologna: Clueb, 2006), 47-65.

8 Jean-Baptiste Labat, Voyages [...] en Espagne et en Italie, vol. 2 (Paris: Delespine, 1730), $260-262$.

9 Johann Wolfgang von Goethe, Italiänischer Reise, ed. by Heinrich Dünker (Berlin: Hempel, 1877), 98-99. 
For 150 years, the structure of the palazzo degli Studi of Bologna was preserved unchanged, except for some necessary renovations and adaptations.

At its inauguration (21 October 1563), the building, located to the left of the Basilica of San Petronio, put on a fine show from the outside. The value of the building was increased by the great open space opposite it, which was created by demolishing the houses and workshops belonging to the vestry of San Petronio. The municipality had to engage in tedious disputes in this regard, which were only resolved when Pope Pius IV promised to provide reimbursements funded by revenues from criminal convictions. The administration and the maintenance of the Archiginnasio were entrusted to the office of the Gabella Grossa, on which both the caretaker of the building and the chaplain of the rebuilt Church of Santa Maria dei Bulgari, which had been incorporated into the ensemble, depended.

According to the original project, in which Morandi, known as il Terribilia, played an important role, terracotta and sandstone, the signature elements of the local architecture, were preferred. Moreover, the exterior of the palazzo, located on two floors around a central courtyard with a double order of loggias, featured a long portico with thirty arches with the main portal inserted in a span of a pre-existing $15^{\text {th }}$ century portico. On the upper floor, accessible by way of two large staircases, the palazzo degli Studi had ten ordinary classrooms and two lecture halls, one for the arts students (artisti) and one for the law students (legisti).

Everywhere in the vaults and on the walls and open galleries, rich decorations, mainly in the form of coats of arms, celebrated the students and the masters of the Studio.

The heart of the building was the double open gallery courtyard. It recalled the sumptuous courtyards of the aristocratic structures of Bologna, although they were actually inspired by the College of Saint Clement of the Spaniards attended by students from Spain, which has been active in Bologna since the Middle Ages. ${ }^{10}$ The most important events relating to university life in Bologna were held there. For instance, the picturesque ceremony of preparing teriaca (theriac)

10 Cf. Michael Kiene, 'L'architettura del Collegio di Spagna di Bologna. Organizzazione dello spazio e influssi sull'edilizia universitaria europea', Il Carrobbio, 9 (1983), 233-242; Michael Kiene, 'L'architettura del Collegio di Spagna e dell'Archiginnasio. Esame comparato dell'architettura universitaria bolognese con quella europea', Annali di Storia delle Università Italiane, 1 (1997), 97-107. 
was performed there. A miraculous electuary made according to a complex and mysterious recipe, it featured many ingredients and was thought to be capable of preventing an endless number of ailments.

A fresco in honour of Benedetto Giustiniani, a Greek cardinal of Genoese origin, can be seen today on the vaulted ceiling of the entrance. It was painted by the Peruvian Diego de León Garavito, the first Bolognese student from the Americas, whose presence between 1607 and 1610; that is, during the same years that Giustiniani was papal legate in Bologna (1606-1611), ${ }_{1}^{11}$ is documented by his personal coat of arms.

The Church of Santa Maria dei Bulgari was located on the eastern side of the courtyard, and its name recalls that of a church that rose in curia Bulgari beside the premises of Bulgaro (d. 1166), the renowned jurist and student of Irnerius. In the church, which was extensively remodelled after World War II, we can still see the Annunciation altarpiece (1582) on the main altar, which was painted by the Flemish artist, Denis Calvaert. The remains of a series of frescoes called Stories on the Life of the Virgin (1591-1594) realised by the Bolognese Bartolomeo Cesi also survived an air raid in 1944.

\section{THE INTERIOR SPACES}

The interior spaces of the Archiginnasio, and the two large staircases that connected the courtyard to the upper floor, were divided between two distinct universitates, that of the law students and that of the arts students.

The staircase for the arts students on the left, which dates back to the $17^{\text {th }}$ century, was characterised by an artistic remembrance of the physician Venceslao Lazzari, painted by Lionello Spada made using hard sandstone with cherubs and allegorical figures. However, the staircase for the law students on the right was dominated by a monument by Giovanni Luigi Valesio (1610-1612) dedicated to

11 On the coat of arms of Diego de León Garavito, student of the Spanish College, cf. España $y$ Bolonia. Siete siglos de relaciones artísticas y culturales, comp. by José Luis Colomer, Amadeo Serra Desfilis (Madrid: Fundación Carolina, Centro de estudios Europa Hispánica, 2006), 168, 178, 181 n. 8, 182 n. 10, 185 n. 57, 186 n. 73. On Giustiniani cf. Ludovico Frati, 'La legazione del Card. Benedetto Giustiniani a Bologna dal 1606 al 1611', Giornale Ligustico di Archeologia, Storia e Letteratura, 14 (1887), 112-122; Andrea Gardi, Lo Stato in provincia. L'amministrazione della Legazione di Bologna durante il regno di Sisto V (1585-1590) (Bologna: Istituto per la Storia di Bologna, 1994), ad indicem. 
San Carlo Borromeo, Cardinal Legate of Bologna at the time the Archiginnasio was founded.

In the open upper gallery, the memory of several of the most renowned Italian physicians and anatomists of the modern era was preserved, which added prestige to the University of Bologna. The bronze portrait of Giovanni Girolamo Sbaraglia (d. 1710), who for forty years was the Chair of Logic and Theoretical Medicine, was created by Giuseppe Maria Mazza based on a drawing by Donato Creti, who also painted the exquisite allegorical figures in the surrounding fresco. The allegory of medicine in honour of the illustrious physician Marcello Malpighi (d. 1694), Sbaraglia's colleague and enemy, was the work of Marcantonio Franceschini. The courtly profile of the physician Antonio Maria Valsalva (d. 1723) was carved by Angelo Piò.

Among the funereal remembrances that would soon decorate the walls of the Studio, the only one executed by a woman (Angela Teresa Muratori, 1706-1707) stands out. It is a cenotaph for two of her ancestors, Francesco and Achille Muratori, both of whom lectured on medicine. The former died from the plague in 1630, and although the fresco was damaged during World War II, the fresco still splendidly conveys the allegorical image of Fame and the figures of Mercury and Aesculapius.

\section{THE ANATOMICAL THEATRE}

The renown of the Bolognese medical school was based not only on the fame of its teachers, but also on the functionality of the places dedicated to the teaching of medicine and anatomy, in particular the so-called Anatomical Theatre. ${ }^{12}$ The construction of a room suited

\footnotetext{
12 On the teaching of medicine in Bologna, see the classical Michele Medici, Compendio storico della Scuola anatomica di Bologna dal rinascimento delle scienze e delle lettere a tutto il secolo XVIII, con un paragone fra la sua antichità e quella delle scuole di Salerno e di Padova (Bologna: Tipografia Governativa della Volpe e del Sassi, 1857). On the places cf. Gualtiero Tonelli, 'Sul Teatro anatomico dell'Archiginnasio: chi furono i padrini?', Strenna Storica Bolognese, 28 (1978), 383-400; Carlo Colitta, Il Palazzo dell'Archiginnasio e l'antico Studio bolognese con il Teatro anatomico. Le funzioni dell'anatomia. Prima esecuzione dello Stabar Mater di Rossini (Bologna: Officine Grafiche Tecnoprint, 1980); Alessandra Frabetti, 'Il Teatro anatomico dell'Archiginnasio, tra forma simbolica e architettura di servizio', L'Archiginnasio. Il Palazzo, l'Università, la Biblioteca, vol. 1 (Bologna: Credito Romagnolo, 1987), 201-218; Chiara Mascardi, 'Teatri della Bologna barocca: la Sala del Podestà, il Formagliari e il Teatro anatomico dell'Archiginnasio (1635-1640)', Strenna Storica Bolognese, 64 (2014), 239-257; Chiara Mascardi, 'Il Teatro anatomico dell'Archiginnasio e la sua architettura. Anatomia di un teatro', Strenna Storica Bolognese, 66 (2014), 270-290.
} 
to the teaching of anatomy, where corpses could be dissected for teaching purposes, similar to the ones that had been built in Padua or Pisa, was urged by the Bolognese Senate as early as 1595. And meanwhile it had been set up in the room where Giulio Cesare Aranzio (d. 1589), the student of the famous Flemish anatomist Vesalius (Andreas van Wesel), taught his classes. But this was a problematic solution and unsuited to accommodating the curious crowds who wanted to attend and observe the operations, especially on the occasion of the feast day of St Anthony the Great. Therefore, it was decided to build a new and larger Anatomical Theatre. ${ }^{13}$ At first, the woodcarver Giovanni Battista Natali was commissioned, but the hall, shaped like an amphitheatre, was later designed in 1637-1638 by the Bolognese architect Antonio Paolucci, known as il Levanti. It was constructed using fir and decorated with two rows of statues: at the bottom there were twelve famous physicians (Hippocrates, Galen, Fabrizio Bartoletti, Girolamo Sbaraglia, Marcello Malpighi, Carlo Fracassati, Mondino de' Liuzzi, Bartolomeo da Varignana, Pietro d'Argelata, Costanzo Varolio, Giulio Cesare Aranzio, Gaspare Tagliacozzi); and, at the top, twenty of the most famous anatomists of the Studio Bolognese (the inscriptions were conceived by the philosopher Ovidio Montalbani). The cathedra of the lecturer, which looms over that of the demonstrator, was flanked by two statues called spellati (skinned men). The canopy was surmounted by the allegorical figure of Anatomy - a seated female receiving a thigh bone as a gift from a winged cherub. The wooden coffered ceiling was made of cedar in 1645 by Levanti, who, with the help of Giovanni Romagnoli and other carvers, decorated it with the symbolic figures of fourteen constellations gravitating around Apollo, the Greek god of healing. The construction of the Anatomical Theatre was completed, at great expense, in 1649. And fortunately, it was decided to postpone the installation of the faux marble decorations on the structural wooden parts, perhaps due to the additional cost involved.

In the first half of the $18^{\text {th }}$ century the anatomical room looked quite rundown. In 1732, Ercole Lelli, already famous for his anatomical sculptures - a bronze statue of his, which has been replicated in gypsum, was displayed at the Bolognese Accademia Clementina and

13 Cf. Francesco Cavazza, Le scuole dell'antico Studio Bolognese (Milano: Hoepli, 1896) (facsimile reprint: Sala Bolognese: Forni, 1987), 256. 
would later be donated to the Academy of St Petersburg - proposed that two new statues of the spellati be placed as the support for the canopy of the cathedra in order to the replace the old ones, but also to prove a better representation of the musculature of the human body. The project was approved, and two years later the two new statues of the Spellati by Silvestro Giannotti from Lucca, carved in lime wood, were put on display. The same artist also renewed and embellished the canopy over the cathedra. In subsequent years, some of the wooden walls in the niches were also replaced. Thus, the classical figures of Avicenna, Paolo Egineta and others were replaced with those of illustrious Bolognese physicians, and they can still be admired on the walls of the Anatomical Theatre today. The central wooden table for displaying the bodies was replaced with a marble top and surrounded by a balustrade of wrought iron and brass (1735).

An air raid on 29 January 1944 destroyed those ancient and marvellous rooms in the Archiginnasio, but a painstaking reconstruction was made possible immediately after the war thanks to the recovery of the original wooden sculptures from among the ruins. During the restoration, the wooden cladding of the walls was completely redone, and based on the original design, the ancient statues were reinstalled in their previous locations. ${ }^{14} \mathrm{~A}$ further modest intervention was conducted in 2006 by the municipal administration of Bologna.

\section{THE STABAT MATER}

As mentioned above, there were ten classrooms on the upper floor of the palazzo. Although they are interconnected today, as they have been converted for use as storage rooms for the Library of the Archiginnasio, they were originally accessed from an open gallery. They were flanked by two large rooms: one for the arts students, today used as the reading room of the library; and one for the law students, today commonly known as the Sala dello Stabat Mater in commemoration of the first Italian performance of Gioachino Rossini's opera, under the direction of Gaetano Donizetti and with

14 Cf. Gennaro De Francesco, 'Il Teatro anatomico di Bologna', La facoltà medica di Bologna (Basilea: Rivista Ciba, 1947), 28-31; Alfredo Barbacci, 'Il restauro del Teatro anatomico dell'Archiginnasio di Bologna', Bollettino d'Arte, 40 (1955), 269-274. 
the participation of the English soprano Clara Novello, the Russian tenor Nikolay Ivanov and the Umbrian contralto Marietta Alboni (18 March 1842). ${ }^{15}$

This room still preserves the solemnity of the initial project, although over time sumptuous congratulatory decorations have been superimposed over the more ancient mural ornamentation. In the mid- $17^{\text {th }}$ century, a monument to honour the Cardinal Legate Fabrizio Savelli (d. 1659) was installed on the southern wall and a large frieze exalting the Germanic natio (1569) was installed at the top. In the middle of the western wall, a large fresco of a Marian subject from 1569 predominated.

\section{UNIVERSITY LIFE AS TOLD BY THE WALLS: THE COATS OF ARMS}

Beginning in 1569, a multitude of coats of arms were installed on the walls of the Archiginnasio, starting with the rooms of the law students.

Therefore, the largest mural heraldic collection in the city was created and it continues to be a focus of admiration for visitors. The coats of arms installed on the walls of the university gave it an authoritativeness and documented its powerful relations. Their function approximated the galleries of the ancestors that were the pride and joy of the aristocratic mansions, documenting the antiquity and prestige of the families. In the same way, the coats of arms of the deans, priors and students ensured the international renown of the Studio, while the cenotaphs of the professors, the celebratory inscriptions and mottos stimulated cultural and moral advancement.

The tutelary deities of scientific and philosophical knowledge, like Aristotle, Empedocles, Democritus and so on, were sure to appear in the decorations, along with the juridical examples, like Justinian, Gregory IX and others. Nor could the protagonists of the reconstruction of the palazzo degli Studi fail to be recalled; either because they were masters, like Aranzi, the renowned anatomist after the inauguration of the Archiginnasio an inscribed stone plaque was laid to commemorate the first dissection performed in the new

15 Cf. Philip Gossett, William Ashbrook, et al., The New Grove Masters of Italian Opera: Rossini, Donizetti, Bellini, Verdi, Puccini (London: Papermac Macmillan, 1983), 59. 
school; or because they were selected to be patrons, like Fulvio della Rovere, Cardinal of Urbino, chosen as protector of the students' university. However, the students also wanted to be represented as part of a universal universitas. The first dated coat of arms was installed in the Annales of the natio Germanica in 1393, and thereafter, many sought to preserve the memory of the priors of the nationes or of the socii who graduated from Bologna. In the representation of all the socii, the counsellors of the different student nations reserved the privilege of placing their family coat of arms in an orderly decorative system. Initially, this involved the rooms of the ground floor and then those on the upper floor, from the grand halls to the lesser ones. The sequence adopted for the arrangement of the coats of arms respected the precedence of the nations established by the statutes. To protect the building, as of the 1830s, the mayors of the Gabella Grossa started to set rules for the new decorative additions, in order to prevent the installation of complex and bulky works; thereby ensuring the care of the existing works and the preservation of the associated memories, and the prevention of any damage. In time, especially, after the $19^{\text {th }}$ century, changes in the use of the property, the inventory, description and analysis of this heraldic legacy became the subject of a careful and profound study of the Imago Universitatis, which is also the title of the ponderous work directed by Gian Paolo Brizzi. ${ }^{16}$

About five thousand coats of arms preserved and legible were installed between the $16^{\text {th }}$ and $18^{\text {th }}$ centuries in the classrooms, corridors, along the staircases and in the vaults of the Archiginnasio. Organised in horizontal strips or adorned by celebratory monuments, the coats of arms bear not only the name and provenance of the student but also the natio the student represented. ${ }^{17}$

Recourse to the coat of arms as a decorative element did not just provide an identity, it actually reflected the process of 'aristocratising' the student population; something that characterised Europe from the $15^{\text {th }}$ century as a repercussion of Humanism, which equated the nobility of knowledge with that of ancestry, and the progressive

16 Cf. Imago Universitatis. Celebrazioni e autorappresentazioni di maestri e studenti nella decorazione parietale dell'Archiginnasio, under the direction of Gian Paolo Brizzi, 2 volumes (Bologna: Bononia University Press, 2011-2012), especially Gian Paolo Brizzi, 'La storia sui muri. Memorie di studenti e maestri nella decorazione dell'Archiginnasio: un nuovo censimento', vol. $1,9-30$.

17 On the formal changes of the decorative apparatus cf. Lorenza Roversi, 'Dalla lapide al monumento barocco: l'evoluzione stilistica delle memorie', Imago Universitatis, vol. 1, 51-80. 
bureaucratisation of the management of the States and the public administrations.

\section{THE ARCHIGINNASIO IN THE $18^{\mathrm{TH}}$ CENTURY}

The solemnity and the lavishness of the rooms of the Studio did not prevent the students - as correctly supposed by Father Labat - from vandalising and defacing them. The papers of Gabella, the institution which had the task of taking care of the place, while documenting the duty of the authority to make the Archiginnasio prestigious, attest to the commitment of the students to continue 'spezzar, ruinare, disgiongere, tagliare in pezzi le catedre sopra le quali ascendono gli eccellentissimi dottori leggenti' (breaking, spoiling, disjoining, cutting into pieces the desks over which ascend the excellent lectors) without even sparing the students' own desks and chairs. The fact that the situation was serious and never-ending was confirmed by the repeated threats of financial penalties, strappado (a torture device) and months in the gaol for those caught red-handed 'dannificare e commettere altri inconvenienti' (damaging and committing other inconveniences) causing disturbances, playing ball games in the inner courtyard and on the square opposite it, throwing stones against the windows and climbing atop the roofs of the building. ${ }^{18}$

Throughout the modern era the maintenance of the palazzo degli Studi was assiduous and costly. The Archiginnasio was constantly equipped with furnishings and consolidated in memory, as has been seen, through the pictorial representation of its most illustrious frequenters, both lecturers and students.

In the early $18^{\text {th }}$ century, as documented by an inventory taken by the prior Giuseppe Maria Zanchetti in 1715, the building was in excellent condition. There was a well in the middle of the courtyard. On the right side of the courtyard, beneath the open gallery, stood the caretaker's house, with several vaulted rooms and a stone chimney; other rooms at his disposal were on the upper floor that was accessed

18 Biblioteca Comunale dell'Archiginnasio di Bologna, Raccolta dei bandi Merlani, 1581, cited in Giancarlo Roversi, 'Il palazzo delle Scuole dal sec. XVI alla fine del Settecento', L'Archiginnasio. Il Palazzo, l'Università, la Biblioteca, vol. 1, ed. by Giancarlo Roversi (Bologna: Credito Romagnolo, 1987), 219-250, 232. For a general overview of student life in Bologna see: Studenti e università degli studenti dal XII al XIX secolo, ed. by Gian Paolo Brizzi, Antonio Ivan Pini (Bologna: Istituto per la Storia dell’Università, 1988). 
from the southern entrance of the staircase. Next to the caretaker's rooms, there was the 'parlour of the doctors in law', a decorous room where the college of legal students met, chaired by its prior pro tempore. It had frescoes and a vaulted ceiling, and wooden benches lining the walls. The 'parlour of the doctors in the arts' was furnished in a similar manner and situated on the opposite side of the courtyard to the left of the Chapel of Santa Maria dei Bulgari.

In the open gallery on the left, some of the spaces, previously used by the chapel but belonging to the Calderini family, were also occupied by the caretaker of the Studio. It had a separate entrance from the road known at the time as 'della Scimmia' (today via Massei) and was accessed by a spiral staircase.

The southern wing of the open gallery had three classrooms, all fitted with wall desks and benches. Another room, beside the Anatomical Theatre, had a fireplace, and next to it there was a small service area.

The Anatomical Theatre, preceded by a wooden panel, was locked with a key. A copy was available to the caretaker, who accompanied any foreigners who wished to visit and admire the building; another was kept by the prior of the Gabella. Some service rooms and a passage beneath the cavea of the theatre, which was accessed by a steep flight of steps, led to rooms situated in the loft. The anatomy teacher was the only one who had use of this space, and it was called the 'small theatre' or 'secret theatre' and used for teaching purposes. However, it was only used in winter when the school was in session; in the summer many of the wooden structures were dismantled and stored, and thereafter, they were reassembled at the start of the new academic year. The key was kept by the incisore (carver) who, in 1715, was named Valsalva.

The Anatomical Theatre was the pride of the University of Bologna. In the mid- $18^{\text {th }}$ century it would have been said: 'Questo teatro tutto è un'opera singolarmente bella in tutte le sue parti' (this theatre, all of it, is a work of singular beauty in all its parts). ${ }^{19}$ In 1734, when it was

19 Archivio di Stato di Bologna, Gabella Grossa, registro n. 830: 'Descrizione degli stabili della Gabella Grossa', n. 4, cited in Roversi, 'Il palazzo delle Scuole dal sec. XVI alla fine del Settecento', 244. 
handed over to Achille Bottrigari, the new caretaker, it was proudly described as follows: ${ }^{20}$

Il suddetto teatro attorno e di sopra è incrostato di legname, ornato di colonne a basso rilievo, corniciotti et altri ornamenti di buona architettura e rabescami, il tutto in legno cirmolo. Nel piano di detto teatro è una tavola di noce per le ostensioni con piede intagliato con coperta di asso sottile alla medesima; attorno di essa una ballaustrata con sportello per riquadro e diversi sedili in più proporzioni alzati in forma che gl'ascoltanti non incommodino gl'uni gl'altri e servono per banchi fino alli muri circondari con le scalinate e piani a loco loco necessari. In una delle facciate piccole vi è una cattedra con baldacchini nuova e due statue con magistria lavorate dal signor Ercole Lelli, fatte fare l'anno presente e rappresentanti la moscolatura dell'uomo in schizzi diversi che sostentano il detto baldacchino et ornano la medesima cattedra. Attorno al suddetto teatro, ripartitamente nelle spalliere, vi sono numero dodici nicchi ornati a intaglio. Nelli due laterali alla cattedra vi sono le due nuove statue rappresentanti Ippocrate e Galeno di mano del signor Silvestro [Giannotti] detto il Lucchese. Sparse poi nel secondo ordine dell'architettura delle dette spalliere attorno di essa stanza vi sono numero venti mezze statue d'uomini illustri, in tanti altri ovati, e cinquantasette armi de' signori amministratori di essa Gabella di legno dorato e colorato.

[The entire aforementioned theatre is encrusted with wood, adorned with low-relief columns, cornices and other good architectural ornamentation and arabesques, all made from pine. On the floor of the said theatre, there is a walnut table with engraved feet and a thin cover for the displays; around it is a balustrade with a door for pictures and several raised seats so that the listeners do not disturb one another and these seats can be used as benches until the walls around, with stairs and floors from time to time necessary. In one of the small facades there is a cathedra with new canopies and two statues made with artistry by master Ercole Lelli. Made this year they represent the musculature of man in different positions and support the said canopy and adorn the same cathedra. Around the said theatre, divided between the espaliers, there are twelve carved niches. On the two sides of the cathedra, there are two new

20 Archivio di Stato di Bologna, Ufficio del registro, Libro delle copie archiviate, Libro 252, cc. 351-357, cited in Roversi, ibidem. 
statues representing Hippocrates and Galen made by master Silvestro [Giannotti], known as il Lucchese. Scattered around the rooms in the second order of the architecture of said espaliers are twenty busts of illustrious men, in many other ovals, and fifty-seven coats of arms of master administrators of the Gabella, which are made of gilded and coloured wood.]

At the northern end of the palazzo was the grand hall for the arts students, fitted with a large desk adjacent to the wall and a number of benches. In the opposite corner of the palazzo was the hall for the law students, the room of the Stabat Mater, that was also dominated by a large desk and furnished with thirty-two benches. The two classrooms were reserved for the most famous and respected teachers, for debates, inaugural addresses and public findings.

The single classrooms were located along the western side of the open gallery and got their light from the windows in the facade. The classrooms had a tall cathedra next to the wall, which was placed high up on a brickwork platform. There was a large wooden canopy above the backrest of the cathedra, with a fresco depicting the Madonna. There were benches in front of the cathedra: more in the central classrooms, and fewer in those located towards the corners. The windows had glass panes and shutters, but many were probably partially walled up over the years.

In the course of the $18^{\text {th }}$ century, the Archiginnasio underwent some small maintenance work, due to the complex life of its inhabitants and the development of many cracks and gaps, which required the installation of various 'keys' to contain the corner walls.

At the end of the $18^{\text {th }}$ century, it was not the poor state of the structures that changed the life in the ancient palazzo degli Studi, but rather the innovations of European politics. Indeed, in 1796, when the French troops led by General Bonaparte arrived in Bologna, the university was also forced to accept the changes laid down in the 1798 General Plan for Public Education, which established four university faculties under the leadership of a single rector. 
Once the Cispadane Republic had been created, the intemperate Jacobins sought to delete the proud heraldic memory of the Ancien Régime in the Archiginnasio in the name of an egalitarian revolutionary society. Only with difficulty was the iconoclastic frenzy of the times dampened, thanks to the intervention of the Academy of Fine Arts, which decreed that the decorations in the entire building should be safeguarded in the name of the nation's art and history.

The historical moment was a particular one. With extreme fugacity, an attempt was made to revive the ancient university in 1799 when it seemed that the Austrians might be able to restore the ancient order. But it was a short-lived moment and the idea was abandoned in 1802, when the law on the reorganization of the studies in the Cisalpine Republic called for the survival of only two universities in the entire state - in Bologna and Pavia. Under these conditions, the ancient Archiginnasio was inadequate to play the role of the University of Bologna: too cramped for the students and uncomfortable for the teachers. It had to be replaced by a larger and more functional location, which was found in the Palazzo Poggi, and where the studies were concentrated in 1803.

The palazzo of the Archiginnasio, for centuries the pride of the city, risked being auctioned off. However, Ferdinando Marescalchi interceded with Napoleon in 1808, and dispelled this risk. Ownership was transferred to the municipality, and after having put up with the Piarist school there for some time, the municipal library was later installed (1838).

Simona Negruzzo: The Archiginnasio, the Seat of the University of Bologna in Modern Times

Keywords: University of Bologna; architecture; Archiginnasio Palace; Antonio Morandi; Church of Santa Maria dei Bulgari; COATS OF ARMS

Simona Negruzzo is Associate Professor of Early Modern History and European History at the University of Bologna. Studied at the University of Pavia in Literature and Philosophy and at the University 
of Strasbourg in History of European Civilization. Received her $\mathrm{PhD}$ in the History of European Society in 1996 at the University of Milan. Her research mainly focuses on the history of educational and cultural institutions (colleges, schools and academies), the history of universities in the early modern period, and related areas. Negruzzo is member of the editorial board of the following journals: Annali di storia delle università italiane; Chrétiens et Sociétés, XVIe-XXIe siècles; Lias. Journal of Early Modern Intellectual Culture and its Sources; Brixia Sacra. Negruzzo is a member of different research centres (CISUI, CeSUP, etc.) and also a member of the Ambrosian Academy of Milan. Recent publications include: $L a$ 'Cristiana impresa'. L'Europa di fronte all'Impero Ottomano all'alba del XVII secolo (2017), Europa 1655. Memorie dalla corte di Francia (2015) and L'armonia contesa. Identità ed educazione nell'Alsazia moderna (2005). 